\title{
Fungicides in the Management of Foliar Diseases of Sesame
}

\author{
B. Meena* and T. Ezhilarasi \\ Regional Research Station, Tamil Nadu Agricultural University, \\ Vridhachalam - 606 001, Tamil Nadu, India \\ *Corresponding author
}

\section{A B S T R A C T}

\begin{tabular}{|l|}
\hline Ke y w or d s \\
Sesame, Alternaria \\
leaf spot, Powdery \\
mildew, Fungicides
\end{tabular}

\section{Introduction}

Among the oilseed field crops, sesame (Sesamum indicum L.) is one of the most important ancient oil-yielding crop in the world for edible oil production. Sesame seed is a rich source of protein $(20 \%)$, edible oil $(50 \%)$, oleic acid (47\%) and linolenic acid (39\%) (Kumaraswamy et al., 2015). It is also a rich source of natural antioxidants viz., sesamoline, sesamin and sesamol (Shyu and Hwang, 2002). Although sesame is widely used for different purposes, it has low productivity due to non-availability of highyielding varieties, resistant variety to biotic and abiotic stresses, low harvest index, seed shattering and indeterminate growth habit.
Many diseases attack sesame, but only a few of them such as Fusarium wilt, charcoal rot, stem and root rot, bacterial blight, bacterial leaf spot, Cercospora leaf spot, Alternaria leaf spot, powdery mildew, leaf curl and phyllody were considered to be the important diseases of sesame in the world and it occurs wherever sesame is cultivated. Among the foliar diseases, leaf blight and powdery mildew were the major disease of sesame in Tamil Nadu. Leaf blight pathogen of sesame, Alternaria sesami attacked all parts of the plant at all stages. Small, dark brown water soaked, round to irregular lesions, with concentric rings, $1-8 \mathrm{~mm}$ in diameter appeared on the leaves. Under excessive atmospheric and soil humidity, the spot increased in size and number. The lesions 
may also appear on the midrib and veins of the leaves. Milder attack caused only defoliation, in severe cases the plants may die. The pathogen is seed borne. Temperature of $20-30^{\circ} \mathrm{C}$ and high humid conditions favoured the disease. Powdery mildew disease of sesame incited by fungus Erysiphe sp. attacked all parts of the plant. Small cottony spots appeared on the infected leaves which gradually spread on the lamina. Defoliation of severely infected plant occurred before maturity.

About one per cent increase in disease intensity reduces its yield by $8.36 \mathrm{~kg} / \mathrm{ha}$ (Maiti et al., 1988). Singh (1987) reported 585 per cent yield losses due to Alternaria leaf spot and fruit rot disease of chilli. Hence, present investigation was undertaken for the management of foliar diseases of sesame using foliar application of fungicides.

\section{Materials and Methods}

\section{Field studies}

The field experiment was conducted in a plot size of $2.4 \times 3.0 \mathrm{~m}$ with eight treatments and three replications in RBD using the susceptible variety VRI-1 for the management of foliar diseases of sesame. Seed treatment (ST) with Trichoderma asperellum @ $10 \mathrm{~g} / \mathrm{kg}$ of seed and furrow application of $T$. asperellum $(2.5 \mathrm{~kg} / \mathrm{ha}$ enriched in $100 \mathrm{~kg}$ of FYM) @ $250 \mathrm{~kg} / \mathrm{ha}$ is common for all the treatments $\mathrm{T}_{1}-\mathrm{T}_{6}$. Five systemic fungicides were selected for the field experiment. The fungicides viz., Myclobutanil, hexaconazole $4 \%$ + zineb $68 \%$, cymoxanil $8 \%$ + mancozeb $64 \%$, trifloxistrobin $25 \%+$ tebuconazole $50 \%$, hexaconazole $5 \%+$ captan $70 \%$ were evaluated against foliar diseases of sesame under field condition. Two spraying of the fungicides were carried out, first at the time of initiation of the disease and second at 15 days after first spraying. In control plots, only water was sprayed. The disease rating was done by 0-5 scale and average disease severity index based on percentage leaf area affected was calculated. The per cent disease intensity (PDI) was worked out.

\begin{tabular}{|l|l|}
\hline Scale & \multicolumn{1}{|c|}{ Per cent leaf area infection } \\
\hline $\mathbf{0}$ & No visible symptoms \\
\hline $\mathbf{1}$ & 1 to $10 \%$ leaf area infected \\
\hline $\mathbf{2}$ & 11 to $20 \%$ leaf area infected \\
\hline $\mathbf{3}$ & 21 to $30 \%$ leaf area infected \\
\hline $\mathbf{4}$ & 31 to $40 \%$ leaf area infected \\
\hline $\mathbf{5}$ & More than 40\% leaf area infected \\
\hline
\end{tabular}

Disease intensity of foliar diseases viz., Alternaria leaf spot and powdery mildew was observed at 75 days after sowing using 0-5 disease rating scale by random selection of 25 plants per plot.

Per cent disease index (PDI) was calculated using the formula

Sum of numerical ratings
PDI = --of plants observed x Maximum grade
Number of
The seed yield was also recorded for each
treatment and the data were statistically
analyzed.

\section{Results and Discussion}

Several systemic fungicides were evaluated for the management of foliar diseases of sesame under field conditions. The results of the field experiment revealed that seed treatment with T. asperellum @ $10 \mathrm{~g} / \mathrm{kg}$, furrow application of $T$. asperellum $(2.5 \mathrm{~kg} / \mathrm{ha}$ mixed in $100 \mathrm{~kg}$ of FYM) @ $250 \mathrm{~kg} / \mathrm{ha}$ followed by foliar spray of myclobutanil @ 1 $\mathrm{g} / \mathrm{l}$ was effective in managing the foliar diseases of sesame which recorded minimum Alternaria leaf spot (13.6 PDI) and powdery mildew (17.2 PDI). This was followed by foliar spray of trifloxistrobin 25\% + tebuconazole 50\%@0.5 g/l which recorded 
Alternaria leaf spot (14.9 PDI) and powdery mildew (18.6 PDI). In control, the maximum Alternaria leaf spot (28.6 PDI) and powdery mildew (33.4 PDI) disease intensity was recorded (Table 1). Pethybridge et al., (2007) reported that berries from the cyprodinil + fludioxonil treatment had the lowest incidence of Botrytis fruit rot of strawberry incited by
Botrytis cinerea. Maximum disease control of chilli leaf spot caused by Alternaria alternata under field conditions by fungicide propiconazole $0.1 \%$ was reported by Gohel and Solanky (2011). Singh and Majumdar (2002) reported propiconazole was the most effective fungicide in controlling fruit rot of pomegranate caused by Alternaria alternata.

Table.1 Integrated management of foliar diseases of sesame (Pooled mean of 2017 and 2018)

\begin{tabular}{|c|c|c|c|c|}
\hline S. No & Treatments & $\begin{array}{l}\text { Alternaria } \\
\text { leaf spot } \\
\text { (PDI) }\end{array}$ & $\begin{array}{c}\text { Powdery } \\
\text { mildew } \\
\text { (PDI) }\end{array}$ & $\begin{array}{c}\text { Yield } \\
\text { (kg/ha) }\end{array}$ \\
\hline $\mathbf{T}_{1}$ & Spray of Myclobutanil @ 1 g/l & $\begin{array}{c}13.6 \\
(21.7)\end{array}$ & $\begin{array}{c}17.2 \\
(24.5)\end{array}$ & 621 \\
\hline $\mathbf{T}_{2}$ & $\begin{array}{l}\text { Spray of hexaconazole } 4 \%+\text { zineb } 68 \% \\
\text { @ } 2 \mathrm{~g} / 1\end{array}$ & $\begin{array}{c}19.8 \\
(26.2)\end{array}$ & $\begin{array}{l}23.5 \\
(28.7)\end{array}$ & 518 \\
\hline $\mathbf{T}_{3}$ & $\begin{array}{l}\text { Spray of cymoxanil 8\%+ mancozeb } 64 \% \\
\text { @ 2g/l }\end{array}$ & $\begin{array}{c}16.2 \\
(23.5)\end{array}$ & $\begin{array}{c}21.3 \\
(27.5)\end{array}$ & 527 \\
\hline $\mathbf{T}_{4}$ & $\begin{array}{l}\text { Spray of trifloxistrobin 25\% + } \\
\text { tebuconazole 50\% @ 0.5 g/l }\end{array}$ & $\begin{array}{c}14.9 \\
(22.5)\end{array}$ & $\begin{array}{c}18.6 \\
(25.1)\end{array}$ & 592 \\
\hline $\mathbf{T}_{5}$ & $\begin{array}{l}\text { Spray of hexaconazole 5\%+ captan 70\% } \\
\text { @ 2g/l }\end{array}$ & $\begin{array}{c}21.4 \\
(27.6)\end{array}$ & $\begin{array}{c}26.7 \\
(30.4)\end{array}$ & 494 \\
\hline$T_{6}$ & $\begin{array}{l}\text { Spray of Trichoderma asperellum @ } \\
0.4 \%\end{array}$ & $\begin{array}{c}23.7 \\
(28.8)\end{array}$ & $\begin{array}{c}28.6 \\
(32.3)\end{array}$ & 486 \\
\hline $\mathbf{T}_{7}$ & $\begin{array}{l}\text { Spray of carbendazim 12\% + mancozeb } \\
63 \% \text { 75WP @ 2g/l (Treated check) }\end{array}$ & $\begin{array}{c}15.3 \\
(22.8)\end{array}$ & $\begin{array}{c}20.9 \\
(26.6)\end{array}$ & 554 \\
\hline $\mathbf{T}_{8}$ & Untreated check & $\begin{array}{c}28.6 \\
(32.3)\end{array}$ & $\begin{array}{c}33.4 \\
(35.8)\end{array}$ & 473 \\
\hline \multicolumn{2}{|r|}{ SEd } & 1.32 & 1.44 & 7.39 \\
\hline \multicolumn{2}{|r|}{$\mathrm{CD}(\mathbf{P}=\mathbf{0 . 0 5})$} & 2.8 & 3.1 & 15.6 \\
\hline
\end{tabular}

*Mean of three replications

Note: Seed treatment (ST) with T. asperellum @ $10 \mathrm{~g} / \mathrm{kg}+$ furrow application of T. asperellum $(2.5 \mathrm{~kg} / \mathrm{ha}$ mixed in $100 \mathrm{~kg}$ of FYM) @ $250 \mathrm{~kg} / \mathrm{ha}$ is common for $\mathrm{T}_{1}-\mathrm{T}_{6}$.

Gholve et al., 2014 highlighted that among the different fungicides tested, thiram was found most effective against A. macrospora, with maximum growth inhibition. Meena and Ratnoo, 2014 observed that mancozeb and hexaconazole were the best fungicides for control of all the three species of A. alternata, A. macrospora and A. gossypina. Wedge et al., (2007) reported that fungicides from seven groups were effective for control of strawberry fruit rot diseases, and the commercial combination fungicides were often the most effective. Total fruit rot was less on berries from the pyraclostrobin + boscalid treatment; anthracnose fruit rot was less on berries from the cyprodinil + fludioxonil treatment; and stem-end rot was less on berries from the cyprodinil + fludioxonil treatment. The significant reduction of the growth of Alternaria solani 
by fungicide mancozeb was reported by Ghazanfar et al., 2016. Sanjeev et al., (2017) documented that among different fungicides, tebuconazole showed significant reduction in mycelial growth of A. alternata in vitro. Rao et al., (2009) documented that among the different integrated seed treatment options tested for the management of Alternaria blight of sunflower, highest benefit was obtained in the seed treatment with Carbendazlm + Iprodione (Quintal) at $0.3 \%$ in water along with hexaconazole foliar spray $(0.1 \%)$.

In addition to disease reduction, the seed yield was also found to be increased in the effective treatment. The maximum seed yield of 621 $\mathrm{kg} / \mathrm{ha}$ was recorded in seed treatment with $T$. asperellum @ $10 \mathrm{~g} / \mathrm{kg}$, furrow application of T. asperellum $(2.5 \mathrm{~kg} / \mathrm{ha}$ mixed in $100 \mathrm{~kg}$ of FYM)@250 kg/ha followed by foliar spray of myclobutanil @ $1 \mathrm{~g} / \mathrm{l}$. Foliar spray of trifloxistrobin 25\% + tebuconazole 50\% @ $0.5 \mathrm{~g} / \mathrm{l}$ ranked next in increasing seed yield which recorded $592 \mathrm{~kg} / \mathrm{ha}$. In control, the minimum yield of $473 \mathrm{~kg} / \mathrm{ha}$ was observed (Table 1). Jayalakshmi et al., (2013) highlighted that soil application of neem cake $(250 \mathrm{~kg} / \mathrm{ha})$ along with seed treatment and soil application $(2.5 \mathrm{~kg} / \mathrm{ha})$ of Trichoderma viride followed by foliar spray of azadirachtin @ 3 $\mathrm{ml} / \mathrm{l}$ on 30 and 45 DAS was effective in managing major sesame diseases by recording minimum disease incidence coupled with maximum seed yield with higher cost benefit $(\mathrm{C}: \mathrm{B})$ ratio.

Hence, it was concluded that foliar diseases of sesame can be effectively managed by foliar application of systemic fungicides.

\section{References}

Ghazanfar, M.U., Raza, W., Ahmed, K.S., Qamar, J., Haider, N. and Rasheed, M.H. 2016. Evaluation of different fungicides against Alternaria solani
(Ellis \& Martin) Sorauer cause of early blight of tomato under laboratory conditions. Int. J. Zoo. Stud., 1: 8- 12.

Gholve, V.M., Jogdand, S.M. and Suryawanshi, A.P. 2014. Evaluation of fungicides, botanicals and bioagents against Alternaria leaf blight caused by A. macrospora in cotton. J. Cotton Res. and Dev., 28: 327-331.

Gohel, N.M., and Solanky, K.U. 2011. Invitro and in-vivo evaluation of fungicies against Alternaria alternata causing leaf spot and fruit rot disease of chilli. Green Farming, 3: 84-86.

Jayalakshmi, C., Nema, S. and Rettinassababady. 2013. Integrated management of sesame diseases. Journal of Biopesticides, 6: 68-70.

Kumaraswamy, H.H., Jawaharlal, J., Ranganatha, A.R.G. and Chander Rao, S. 2015. Safe sesame (Sesamum indicum L.) production: Perspectives, practices and challenges. Journal of Oilseeds Research, 32: 1-24.

Maiti, S., Hegde, M.R. and Chattopadhyay, S.B. 1988. Handbook of Annual Oilseed Crops. Oxford and IBH Publ. Co. Pvt. Ltd., New Delhi.

Meena, P.K. and Ratnoo, R.S. 2014. Efficacy of fungicides and phytoextracts against leafspot on cotton. Int. J. Agri. Sci., 10: 115-118.

Pethybridge, S.J., Hay, F.S., Wilson, C.R. and Groom, T. 2007. Development of a fungicide-based management strategy for foliar disease caused by Phoma ligulicola in Tasmanian Pyrethrum fields. APS Publications, 89: 1114.

Rao, L., Kulkarni, S., Sattigarahalli, L. 2009. Bio-priming of seeds: A potential tool in the integrated management of alternaria blight of sunflower. Helia, 32: 107-114.

Sanjeev, P.J., Mesta, R.K., Biradar, I.B., Sadanand, K.M and Ajjappalavar, P.S. 2017. Int. J. Curr. Microbiol. App. 
Sci., 6: 495-504.

Shyu, Y.S.S. and Hwang, L.S. 2002. Antioxidant activity of white and black sesame seeds and their hull fractions. Food Research International, 35: 357-365.

Singh, J. and Majumdar, V.L. 2002. Fungicidal management of Alternaria rot in pomegranate. J. Mycol. Pl. Path., 32: 134.
Singh, S.N. 1987. Response of chilli cultivars to Alternaria alternata and losses under field conditions. Farm Sci. J., 2: 96-97.

Wedge, D.E., Smith, B.J., Quebedeaux, J.P. and Constantin, R.J. 2007. Fungicide management strategies for control of strawberry fruit rot diseases in Louisiana and Mississippi. Crop Protection, 26: 1449-1458.

\section{How to cite this article:}

Meena, B. and Ezhilarasi, T. 2019. Fungicides in the Management of Foliar Diseases of Sesame. Int.J.Curr.Microbiol.App.Sci. 8(06): 3086-3090.

doi: https://doi.org/10.20546/ijcmas.2019.806.368 